Lifelong Learning. September $2005 . \quad$ URL: https://uil.unesco.org/document/hungary-strategy-government-republichungary-lifelong-learning-issued-2005 [in English]

Lietuva 2030. (2020). Lithuania's Progress Strategy. URL: https://Irv.It/uploads/main/documents/files/EN_version/Useful_information/li thuania2030.pdf [in English]

Recommendation of the European Parliament and of the Council of 18 December 2006 on key competences for lifelong learning. (2006). Official Journal of the European Union. URL: https://eurlex.europa.eu/LexUriServ/LexUriServ. do?uri=OJ:L:2006:394:0010:0018:en:PDF [in English]

Sustainable Development Strategy of Latvia until 2030. SAEIMA of the Republic of Latvia. (2020). URL: https://www.pkc.gov.Iv/sites/default/files/inlinefiles/LIAS_2030_en_1.pdf [in English]

The European Agenda for Adult Learning. (2010). URL: https://eur-lex. europa.eu/legalcontent/EN/TXT/HTML/?uri=CELEX:32011G1220 (01)\&from=EN [in English]

УДК 37.018.43:[044+621.397.122]

DOI: https://doi.org/10.35387/od.1(17).2020.29-39

Головченко Гліб Олександрович - кандидат педагогічних наук, дочент, директор Коледжу преси та телебачення, м. Миколаїв

ORCID iD: http://orcid.org/0000-0003-1734-6430

E-mail:g.golovchenko@gmail.com

\title{
АНАЛІЗ ДІЯЛЬНОСТІ ЦЕНТРІВ МЕДІАОСВІТИ В УКРАÏНІ
}

Анотація. Автором оглядової статті наголошено, що епоха цифрового суспільства вимагає від нинішніх громадян вільного володіння новими навичками для успішного використання можливостей новітньої реальності - медіаінформаційними. Відтак, все більшої вагомості набуває медіаосвіта. ЮНЕСКО навіть визнає медіа освіту окремою складовою освіти. Україна вже має певний позитивні здобутки з ії провадження у формальній, нефоормальній та інфоормальній освіті. У публікації здійснено спробу систематизувати набутий досвід через призму діяльності вітчизняних медіаосвітніх центрів.

Для досягнення поставленої мети було використано комплекс теоретичних методів дослідження для вивчення напрямів провадження вітчизняної медіаосвіти: огляд літератури, відбір $i$ й осмислення результатів, їх систематизація та визначення перспектив. Описано діяльність 3 визнаних вітчизняних иентрів медіаосвіти: Інституту соціальної та політичної психології, Інституту вищої освіти Національної академії педагогічних наук України та Інституту екології масової інфрормації. Узагальнення та систематизація їх медіаосвітньої діяльності уможливили виокремлення наступних критеріїв: історичного, методичного, прогностичного.

Завдяки їх використанню, було визначено й 2 нових медіаосвітніх 
центри в Україні: Академія преси України та Коледж преси та телебачення у м. Миколаїв. У статті проаналізовано історію їх створення, особливості розроблення та впровадження науковонавчально-методичного забезпечення, окреслено напрями їх подальшої діяльності. Таким чином, через діяльність визначених центрів медіаосвіти було простежено тенденції ії розвитку на ринку освітніх послуг України. З‘ясовано, що всі медіаосвітні центри є схожими за своєю місією - медіапросвітницькою діяльністю. Водночас їх відмінності проявляються в практичному провадженні медіаосвіти. У подальшому планується дослідити особливості медіаосвітньої діяльності в дистанційному форматі, зумовленого пандемією COVID 19.

Ключові слова: медіаосвіта, центри, Україна, медіаосвітня діяльність, аналіз.

Golovchenko Glib - Candidate of Pedagogical Sciences, Associate Professor, Director of College of Press and Television, Mykolaiv

ORCID iD: http://orcid.org/0000-0003-1734-6430

E-mail:g.golovchenko@gmail.com

\section{ANALYSIS OF MEDIA EDUCATION CENTRES' ACTIVITY IN UKRAINE}

Abstract. Currently the age of digital society requires its members to freely acquire new skills for the successful use of the possibilities of the new digital reality - media and information literacy. As a result, media education, which is recognized by UNESCO as a separate field of education, is becoming increasingly important. Ukraine has already some positive achievements in the sphere of media education.

The paper is aimed at systematizing the experience gained by Ukraine through the prism of media education centers' activity. To achieve the established goal, a set of theoretical research methods was used. Thus, a review of the literature, selection and interpretation of results, their systematization and identification of prospects were applied. The article describes the activity of 3 recognized domestic centers of media education: the Institute of Social and Political Psychology, the Institute of Higher Education of the National Academy of Pedagogical Sciences of Ukraine and the Institute of Ecology of Mass Information. Generalization and systematization of their media educational activities made it possible to distinguish the following criteria: historical, methodological, prognostic. Thanks to their use, 2 new media educational centers were identified: Academy of Press of Ukraine and the College of Press and Television in Mykolayiv. The history of their creation, peculiarities of development and introduction of scientific, educational and methodical maintenance are analyzed, the directions of their further activity are outlined.

Thus, the analysis of media education trends in Ukraine is done through the activity of the media education centres. A study of the media educational activities of these centers led to the conclusion that they are all 
similar in their mission - media education. At the same time, they have unique features that are manifested in the practical implementation of media education. It is planned to investigate the peculiarities of media education activity that was totally conducted in the distant form due to COVID 19 pandemic.

Key words: media education, centres, Ukraine, media education activity, analysis.

Постановка проблеми, іï актуальність. Кардинальні трансформації сучасного суспільства, зумовлені процесами глобалізації, інформатизації, інтеграції, проявляються вже у всіх сферах діяльності людства: економічній, технологічній, соціальній, і водночас у викликах, які ще потребують свого вирішення. Одним із таких викликів є надзвичайний масив інформації, доступний кожній людині лише за одним порухом мишки. Епоха цифрового суспільства вимагає від нинішніх громадян вільного володіння новими навичками для успішного використання можливостей новітньої реальності. Серед особливо вагомих навичок, які вважаються життєво необхідними, є медіаосвітні, чи як їх нині називають медіаінформаційні. Медіаосвіта має розвивати в комплексі технічні, когнітивні, соціальні, громадянські та творчі здібності, які дозволять кожному громадянину отримати вільний доступ до інформації, оволодіти навичками критичного мислення, свідомо й відповідально взаємодіяти 3 медіа та один з одним. ЮНЕСКО визнає медіаосвіту окремим напрямом освіти, оскільки вона допомагає людині усвідомити способи використання масової комунікації в суспільстві; аналізувати медіатексти та критично оцінювати запропоновані в них цінності, політичні, соціальні, комерційні та культурні інтереси, а також створювати і ширити через мас-медіа власні медіатексти (Recommendations, 1999).

Усвідомлюючи роль медіаосвіти у розвитку соціальновідповідального суспільства та з урахуванням викладеного вище, провідні країни світу почали активно впроваджувати медіаосвіту в освітній процес ще з середини минулого століття і натепер набули важливого досвіду як у розвитку медіаосвітніх навичок суб‘єктів навчання: учнів, студентів і педагогічного персоналу, підростаючого покоління і дорослих, так і у формальній і неформальній освіті. У порівнянні з ними, Україна ще тільки робить перші кроки в цьому напряму, проте вже має певні здобутки.

Аналіз основних досліджень і публікацій. Зважаючи на викладене вище та з метою більшої популяризації результатів наукових пошуків саме вітчизняних науковців, в цій частині викладу здійснимо аналіз основних наукових публікацій винятково українських вчених. Загалом, аналіз вітчизняної наукової літератури з теми дослідження свідчить про глибокий інтерес вітчизняних науковців до проблем теоретичного, так і практичного характеру провадження медіаосвіти. Фундаментальні основи медіаосвіти та медіаграмотності, її концептуальні засади розкрито у низці досліджень таких українських вчених, як В. Іванов, Т. Іванова, О. Ковнещинська Г. Онкович, Б. Потятинник, Г.Почепцов. Значного поширення набули дослідження, в яких висвітлено особливості практичної 
реалізації медіаосвіти у закладах освіти України (О. Боришполець, Р. Бужиков, О. Волошенюк, Л. Найдьонова та ін.).

Варто згадати, що питання сучасного стану і перспектив розвитку медіаосвіти в Україні були предметом аналізу в роботах Д. Бачинського, М. Коропаткина, Т. Слабошевської, І. Смекаліна. Разом з тим, зважаючи на динаміку змін у галузі медіаосвіти, нові напрацювання вчених і практиків, ситуація з медіаосвітою та медіаграмотністю населення не $є$ фіксованою раз і назавжди: простежуються нові медіаосвітні тенденції, набувається та поширюється досвід провадження медіаосвіти, з'являються нові виклики. Відтак, актуальним і цілком логічним, на нашу думку, є звернення до аналізу стану медіаосвіти в Україні та систематизації набутого нею досвіду.

Мета дослідження полягає в систематизації досвіду провадження медіаосвіти, набутого Україною, через призму діяльності медіаосвітніх осередків, та окресленні перспектив їх подальшого розвитку. 3 огляду на мету дослідження, методами для ії досягнення слугували теоретичний аналіз наукової, навчально-методичної літератури з проблеми вітчизняної медіаосвіти та значного масиву інформації з інтернет джерел; відбір та осмислення отриманих результатів з подальшою їх систематизацією за визначеними критеріями. Використання прогностичних методів дозволило окреслити напрями подальшої діяльності центрів медіаосвіти в Україні.

Виклад основного матеріалу дослідження. Описуючи медіаосвітню діяльність, що проводиться на теренах України, вітчизняні дослідники медіаосвіти Т. Слабошевська, І. Смекалін (2013) та ін. визнають, що сьогодні в Україні діють три потужних осередки медіаосвіти у м. Києві (Інститут соціальної та політичної психології та Інститут вищої освіти Національної академії педагогічних наук України) та у м. Львові (Інститут екології масової інформації). Всі три центри активно займаються створенням навчальних програм та посібників, організовують наукові конференції, присвячені медіаосвіті та працюють над проблемою впровадження такого напряму в освітні заклади України.

Аналіз діяльності зазначених осередків, на нашу думку, відобразить тенденції розвитку медіаосвіти в Україні, сприятиме визначенню ії особливостей та окресленню перспектив подальшого її розвитку. Розкриваючи їх медіаосвітню діяльність, особливу увагу звернемо на такі аспекти: історичний (простежимо історію створення осередку), методичний (здійснимо аналіз діяльності з позицій розроблення та популяризації науково-навчально-методичного забезпечення медіаосвіти), прогностичний (окреслимо перспективи діяльності на майбутнє). Ці аспекти слугуватимуть нам критеріями, за якими й буде проаналізовано діяльність центрів медіаосвіти в Україні.

Одним із перших вітчизняних медіаосвітніх осередків стала Лабораторія психології масової комунікації та медіаосвіти, яку очолює відома українська дослідниця Л. Найдьонова, доктор психологічних наук. Лабораторію створено у 2006 р. як перший в Україні науковий підрозділ, що має за мету відстеження рівня медіакультури шкільної молоді та дорослого населення, осмислення методологічних і методичних підходів до 
розгортання медіаосвіти в системі загальноосвітньої школи (Лабораторія, 2020 ). Основою для її створення послугували багаторічні теоретикометодологічні здобутки досліджень інформаційного простору України, що проводились Інститутом соціальної та політичної психології з 1994 р. під керівництвом член-кореспондента НАПН України М. М. Слюсаревського.

Нині Лабораторія займається дослідженнями соціальнопсихологічних аспектів масової комунікації та організації медіаосвіти молоді, питаннями фрормування у неї психологічної стійкості до соціально шкідливої інформації, готовності до ефективної взаємодії з інфрормаційним простором. Науково-педагогічний колектив має вагомі результати проведених досліджень, 3 поміж яких назвемо розробку Концепції впровадження медіаосвіти в Україні 2010 р. та ії нову редакцію 2016 р. (Концепція, 2010; 2016); створення та реалізація на практиці вітчизняної соціально-психологічної моделі медіаосвіти, що поєднує в собі елементи захисного, естетичного, громадянського і творчого підходів; проведення Всеукраїнського медіаосвітнього експерименту; здійснення моніторингу медіакультури молоді. Також дієвими заходами 3 провадження медіаосвітньої діяльності Лабораторії є проведення медіаосвітніх шкіл і семінарів з практичної медіа освіти та розробка програм і методичного забезпечення шкільної та позашкільної медіаосвіти.

Привертає увагу діяльність однієї із таких медіаосвітніх шкіл, що створена на базі Київського університету імені Б. Грінченка. У 2019 р. медіашкола офіційно відкрила четвертий сезон, початок якої було покладено сертифрікатною програмою «Медіакомпетентність» для педагогів та психологів, для яких важливо знати найактуальніші тренди зі світу медіакомунікацій. Першими слухачами школи стали понад 80 учасників: директори шкіл, педагоги, викладачі, психологи з усієї України. Сьогодні тематика тренінгів медіашколи досить різноманітна: медіабезпека, медіапсихологія, медіавиробництво та сучасні медіа технології. Перспективними напрямами роботи вказаного медіаосвітнього центру є:

- проведення досліджень медіапсихологічних засобів профрілактики та подолання наслідків деструктивних інформаційних впливів на дітей та молодь;

України;

- масове інтенсивне впровадження медіаосвіти в усіх областях - включення до стандартів фахової підготовки та підвищення кваліфрікації шкільних учителів за медіаосвітнім напрямом медіаінформаційної грамотності, медіакомунікаційної компетентності та критичного мислення;

- розвиток громадського медіаосвітнього руху;

- формування медіапсихологічної компетентності виробників медіа щодо захисту дитини в інформаційному просторі

- дослідження френомену психології медіатравматизації та шляхи подолання наслідків інформаційної війни, ролі медіа в психологічній реабілітації (Лабораторія, 2020).

Ще одним потужним центром медіаосвіти в Україні донедавна 
вважався Інститут вищої освіти НАПН України, де під керівництвом знаного вітчизняного науковця у галузі медіаосвіти, лінгводидакта, медіапедагога Г. Онкович з 2000 р. до 2015 р. функціонував відділ теорії та методології гуманітарної освіти (Бачинський, 2018). Серед завдань, які виконувалися працівниками відділу, варто назвати упровадження медіаосвіти у систему вищої освіти за допомогою інтегрування медіаосвітніх технологій у професійну підготовку майбутніх спеціалістів; науково-методичне забезпечення різноманітних медіаосвітніх стратегій; розвиток медіаосвітньої культури фахівців як необхідного складника професійної культури (Онкович, 2013). Дослідження, що проводилися цим відділом та успішно захищені дисертації з медіаосвіти - свідчення того, що у питання використання мас медіа в освітньому процесі, зокрема у вітчизняній вищій школі, $€$ нагальним та актуальним. Творчим здобутком наукових працівників відділу стала низка авторських програм медіаосвітнього спрямування, які пройшли апробацію в освітніх закладах України.

У 2018 р. Г. Онкович - професор Київського національного медичного університету імені О. Богомольця, завідувач науководослідницької лабораторії «Формування особистості студента» цього ж вишу. Завдяки науковцям лабораторії реалізується авторський культурноосвітній проект 3 медіаосвіти «Школа медіаосвіти на Кінбурні», розроблений професором Г. Онкович. Проектом передбачено проведення тренінгів та майстер-класів для вчителів загальноосвітніх шкіл, консультацій з блоково-тематичного планування навчальних тижнів, науково-педагогічні читання та багато іншого (Борко, 2018). Експериментальним майданчиком для реалізації проекту стала Покровська ЗОШ (с. Покровка, Кінбурн). Перспективами подальшої медіаосвітньої діяльності наукової школи Г. Онкович $є$ розробка і провадження нової концепції професійної підготовки, яка включає медіаосвітні стратегії 3 метою формування медіаосвітньої культури як необхідної складової професійної культури майбутнього фахівця (Онкович, 2016). Таким чином, цей осередок медіаосвіти можна ототожнити 3 науковою школою професора Г. Онкович, яка, фактично, і $€$ тим генератором прогресивних ідей, наукових досліджень та реалізацій їх результатів у практиці діяльності закладів вищої освіти України. Нині її учні та послідовники активно впроваджують ідеї медіаосвіти не лише в навчальний процес закладів середньої та вищої освіти, але й також у післядипломну освіту, зокрема через введення навчального курсу «Основи медіаосвіти» на курсах підвищення кваліфікації педагогічних працівників. Цей та подібні йому курси забезпечують «не лише формування знань із теорії медіаосвіти, а й, головне, формування вмінь професійно використовувати набуті знання в педагогічній практиці» (Слабошевська, Смекалін, 2013, с. 13).

Інститут екології масової інформації, створений ще у 1999 р. на базі Львівського національного університету імені Івана Франка, результати його наукової та прикладної діяльності, є свідченням того, що Інститут, по праву, вважають одним із осередків медіаосвіти в Україні. Науководослідницька діяльність Інституту зосереджена на трьох основних 
напрямах: медіафілософському (осмисленні функціонування та впливу масової комунікації, зокрема медіатехнологій, на культуру і цивілізацію), медіакритичному (аналіз медіа дискурсу) та медіаосвітньому, спрямованому на поширення знань про мас медіа серед широкого загалу, зокрема щодо психологічних загроз, пов'язаних 3 пропагандою і фальсифікацією, порнографією та екранним насильством (Інститут, 2020). Таким чином, інформаційне довкілля, середовище, створене, передусім, засобами масової інформації, $€$ об‘єктом досліджень Інституту екології масової інформації.

Натомість, прикладна спрямованість діяльності Інституту реалізується через розвиток в Україні медіаекології та медіаграмотності. Медіаекологія концентрується на фрілософському осмисленні впливу масової комунікації, у тому числі й медіатехнологій, на людську психіку зокрема і культуру загалом. Розвиток медіаграмотності передбачає більш прикладні аспекти, наприклад, як вберегти психіку дітей і підлітків від надміру насильства і порнографії (Інститут, 2020). У 2012 р. Інститут реалізував проєкт «Майстерні громадської медіакритики» спільно 3 кафедрою журналістики Таврійського національного університету ім. В. Вернадського та Регіональним центром медіаосвіти та медіапсихології. Проєкт передбачав організацію та проведення публічних лекцій, круглих столів та дискусійних семінарів з провідними українськими журналістами та дослідниками медіа з актуальних проблем медіаосвіти та медіакритики.

Перспективами подальшої науково-прикладної діяльності Інституту екології масової інформації $\epsilon$ реалізація нових проєктів: «Медіаосвіта» та «Медіакритика». Наприклад, перший проєкт має на меті поєднати дослідження негативного психологічного впливу медіа (зокрема екранного насильства, порнографії, надмірної реклами, фальсифікації та пропаганди) з розробкою відповідних методик роботи 3 молоддю, які б дозволили виробляти більш критичне сприйняття названих різновидів патогенної медіапродукції та формувати психологічну опірність до їхнього впливу (Проекти, 2020).

На нашу думку, окрім описаних вище центрів медіаосвіти, варто згадати й Академію української преси (АУП) з її потужним науковим і навчально-методичним ресурсом забезпечення медіаосвіти в Україні. АУП $\epsilon$ неприбутковою, неурядовою та незалежною організацією, що була заснована у 2001 р. та підтримується європейськими та американськими організаціями. Ії̈ президентом $€$ В.Ф. Іванов, а одним із засновників Г. Г. Почепцов - знані в Україні та за кордоном вчені, пріоритетом наукових інтересів яких $є$ медіаосвіта та її провадження в Україні. Місія АУП полягає у сприянні поінформованого та критичного споживання медіа українським суспільством та дотримання стандартів соціально-відповідальної журналістики в Україні. Виконання місії можливе через просування медіаосвіти громадян, створення медіаосвітньої мережі, створення та популяризація інформаційного продукту, який покликаний підвищувати рівень медіаграмотності суспільства, організація різних заходів, в результаті яких працівники мас-медіа будуть виконувати свої професійні 
обов'язки відповідно до європейських норм та стандартів (АУП).

Для нашого дослідження вартим уваги $€$ діяльність АУП, що спрямована на формування та підтримку медіапедагогів для початкової, середньої та вищої освіти завдяки: підготовці навчальних і методичних посібників для різних аудиторій; розробленню онлайн ресурсів для провадження медіаосвіти у нефрормальній та інформальній освіті; залученню світового досвіду з впровадження медіаосвіти; створенню можливостей для медіаосвіти упродовж життя в партнерстві з бібліотеками та громадським сектором, зокрема створенню програм навчальних курсів; проведенні літньої та зимової школи АУП; організації та проведенні міжнародних науково-методичних конференцій «Практична медіаграмотність: міжнародний досвід та українські перспективи»; наповненню та просуванню Бібліотеки масової комунікації та медіаграмотності, що містить кращі світові зразки практичних посібників 3 журналістики, медіаосвіти та праць з масової комунікації, які допомагають українським журналістам та освітянам підвищити свій загальний професійний рівень (АУП , 2020). АУП широко використовує у своїй діяльності апробовані медіаосвітні методики розвитку медіаграмотності дітей та молоді, а саме розробляє та популяризує онлайн медіаосвітні ігри, наприклад «Медіазнайка» та «Пригоди Літератуса». Щороку АУП проводить науково-методичні конференції за підтримки авторитетних міжнародних i європейських організацій, присвячені проблемам медіаосвіти, зокрема її теоретичним й світоглядним засадам, практичним аспектам розвитку медіаграмотності у дошкільних навчальних закладах та початковій школі, в середніх загальноосвітніх закладах; організаційним та управлінським моделям упровадження медіаосвіти, розвитку медіаінформаційної грамотності.

Для донесення своїх здобутків до більшого кола зацікавлених осіб, а також для сприяння спілкування медіапедагогів у вересні 2013 р. АУП створила інтернет портал «Медіаосвіта і медіаграмотність». Портал має сторінки для: вчителя середньої школи (з градацією по групам класів), для викладачів ЗВО та для медіаспоживачів; мапу медіаосвітніх ініціатив України; розділ новин медіаосвіти; електронну бібліотеку, календар подій, плани уроків, презентації тощо. Нині його активними користувачами $є$ понад 3 тис. осіб (Портал, 2020).

Не можемо не визнати вагомих й очевидних здобутків зазначених наукових шкіл, які вже стали відомими осередками медіаосвітньої діяльності й навколо яких гуртуються медіаосвітня педагогічна спільнота й громадські об‘єднання та організації. Проте, на нашу думку, варто виокремити ще один медіаосвітній центр, який досяг значних результатів у впровадженні медіаосвіти в навчальний процес, у формуванні наукового підґрунтя, навчально-методичного забезпечення медіаосвітнього процесу м. Миколаїв. Новим, однак вже добре відомим вітчизняним медіаосвітянам і науковцям осередком медіаосвіти, став Коледж преси та телебачення. Коледж преси та телебачення - єдиний в Україні недержавний вищий освітній заклад II рівня акредитації, який здійснює підготовку фахівців для 
засобів масової комунікації з 1993 року. Місія Коледжу полягає у створенні умов для функціонування відкритого демократичного суспільства в Україні шляхом підготовки нових фрахівців для дійсно демократичних $3 \mathrm{MI}$ (Головченко, 2019).

В основу підготовки фахівців в Коледжі преси та телебачення покладено базову педагогічну технологію, яку було розроблено та впроваджено науково-педагогічних складом освітнього закладу дидактичний інформаційний простір (ДІП) - система організаційнопедагогічних заходів, що забезпечують створення умов, які сприяють прискореному формуванню професійних якостей особистості та творчому засвоєнню знань. Науково-педагогічний персонал Коледжу не лише готує майбутніх репортерів, але й активно займається питаннями розбудови та науковими пошуками у сфері медіаосвіти та ії̈ впровадження в інші освітні заклади в Україні. Автор є директором згаданого Коледжу і безпосередньо очолював процес формування і впровадження медіаосвітніх технологій в навчальний процес.

Зважаючи на викладене вище, можна констатувати, що в Україні діє 5 центрів медіаосвіти (рис. 1).

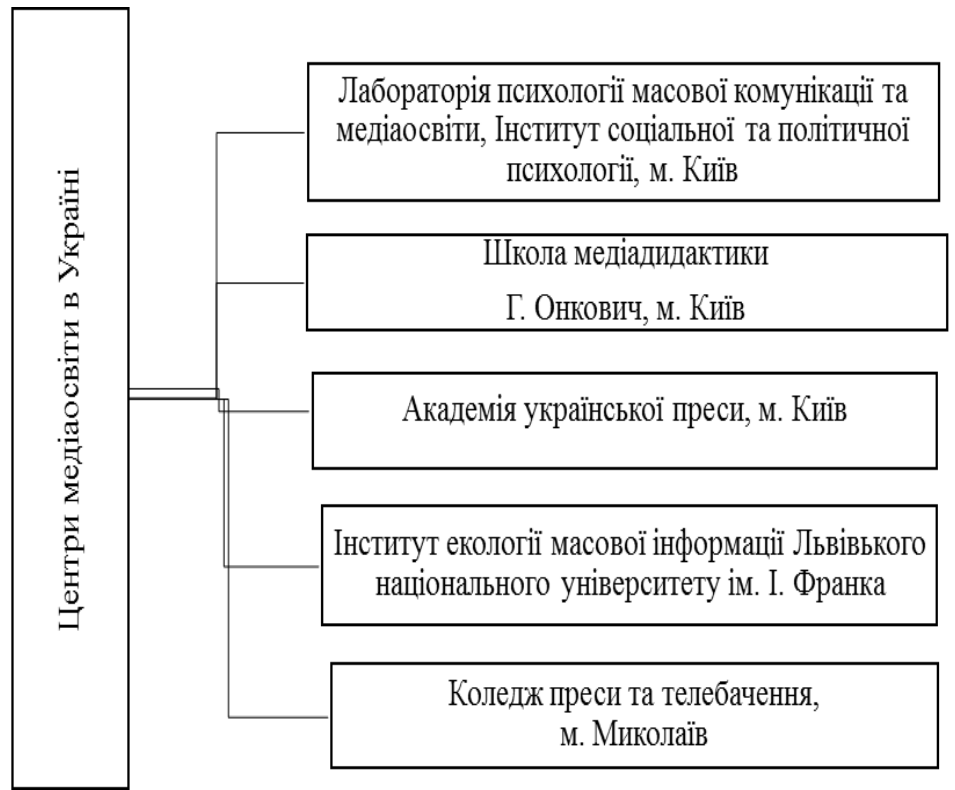

Рис. 1. Центри медіаосвіти в Україні. Джерело: розроблено автором.

Висновки і перспективи подальших досліджень. Зважаючи на викладене вище, можемо констатувати, що нині на теренах України 
активно функціонують не три, а п'ять центрів медіаосвіти. Кожен з них має свої особливості. Разом з тим, їх обєєднує те, що всі вони провадять науково-дослідну роботу, і водночас імплементують її результати у свою практичну діяльність. Завдяки цим центрам створюється належне навчально-методичне забезпечення медіаосвітньої діяльності для вітчизняних загальноосвітніх шкіл і вищих освітніх закладів. Саме їхніми зусиллями пропагується медіаосвіта. Вони гуртують навколо себе громадські організації та об‘єднання, діяльність яких націлено на медіа просвітницьку діяльність для широкого загалу. Перспективи подальших досліджень вбачаємо в аналізі нових тенденцій в провадженні медіаосвіти в Україні, зокрема в умовах тотального дистанційного освітнього процесу, зумовленого поширенням COVID-19.

\section{Список використаних джерел}

АУП. (2020). Академія української преси. https://www.aup.com.ua/

Бачинський, Д. (2018). Медіаосвіта в системі сучасних закладів: вітчизняний та зарубіжний досвід. Педагогіка. 25 (2-2018), 9-24. DOI: 10.32626/23099763.2018-25.19-25

Борко, Т. (2018). Уроки Школи медіаосвіти на Кінбурні. Культура і життя. 41, $10-11$.

Головченко, Г. (2019). Соціальна роль медіаосвіти в умовах глобалізаційноінформаційних змін. Освіта для миру = Educacja dla pokoju. К.: Видавництво ТОВ «Юрка Любченка».

$\begin{array}{llll}\text { Інститут екології масової інформації. } & \text { (2020). }\end{array}$ http://institutes.Inu.edu.ua/mediaeco/

Концепція впровадження медіаосвіти в Україні. (2010). Постанова Президії Національної академії педагогічних наук України від 20 травня 2010. URL: $\quad$ https://lobtimucoz.ua/Mediaosvita/001konsepsiavprovadzenna mediaosvity.doc.pdf

Концепція впровадження медіаосвіти в Україні. (2016). Постанова Президії Національної академії педагогічних наук України 21 квітня 2016 р. URL: www.mediaosvita.com.ualmateriall

Лабораторія психології масової комунікації та медіаосвіти. (2020). Офіційний сайт. http://mediaosvita.org.ua/pro-nas/

Онкович, Г. В. (2016). Медіапедагогіка. Медіаосвіта. Медіадидактика. Вища освіта України. 2, 63-69.

Онкович, Г. (2013). Медіадидактика вищої школи: український досвід. Вища освіта України. 1, 23-29.

Портал «Медіаосвіта і медіаграмотність». (2020). URL: http://medialiteracy.org.ua/

Проекти. (2020). Інститут екології масової інформації. http://institutes.Inu.edu.ua/mediaeco/research/projects/\#

Слабошевська, Т. М., Смекалін, І. М. (2013). Медіаосвіта в Україні: сучасний стан $і$ перспективи розвитку. URL: http://enpuir.npu.edu.ua/bitstream/123456789/4709/1/Slaboshevska_Smekalin.pdf

Recommendations Addressed to the United Nations Educational Scientific and Cultural Organization UNESCO. (1999). Education for the Media and the Digital Age. Vienna: UNESCO, 273-274. 


\section{References(translated and transliterated)}

AUP (2020). Akademija ukrajinsjkoji presy [Academy of Ukrainian Press]. https://www.aup.com.ua/ [in Ukrainian].

Bachynskyi, D. (2018). Mediaosvita v systemi suchasnykh zakladiv: vitchyznjanyj ta zarubizhnyj dosvid. [Media education in modern institutions: domestic and foreign experience]. Pedagogics: collection of scientific papers. 25 (22018), 19-24. doi: 10.32626/2309-9763.2018-25.19-25 [in Ukrainian].

Borko, T. (2018). Uroky Shkoly mediaosvity na Kinburni [Lessons of Media Education School in Kinburn]. Culture and Life. 12 October, 2018, 41, 1011 [in Ukrainian].

Koncepcija vprovadzhennja mediaosvity v Ukrajini. [Concept of Media Education Activity in Ukraine]. (2010). Resolution of the Presidium of the National Academy of Pedagogical Sciences of Ukraine from 20, May, 2010. URL: https://lobtimucoz.ua/Mediaosvita/001konsepsiavprovadzennamediaosvity. doc.pdf [in Ukrainian].

Koncepcija vprovadzhennja mediaosvity v Ukrajini. [Concept of Media Education Activity in Ukraine]. (2016). Resolution of the Presidium of the National Academy of Pedagogical Sciences of Ukraine from 21, April, 2016. www.mediaosvita.com.ualmaterial \[in Ukrainian].

Golovchenko, G. (2019). Socialjna rolj mediaosvity v umovakh ghlobalizacijnoinformacijnykh zmin. [Social role of media education in the conditions of global and information changes]. in V. Kremen, V. Kotsur, N. Nychkalo (Ed.). Education for Peace/Educacja dla pokoju. In 2 volumes. Kyiv: Yurko Liubchenko Publishing House [in Ukrainian].

Instytut ekologhiji masovoji informaciji. [Institute of Ecology of Mass Information]. (2020). URL: http://institutes.Inu.edu.ua/mediaeco/ [in Ukrainian].

Laboratorija psykhologhiji masovoji komunikaciji ta mediaosvity. [Laboratory of Psychology of Mass Communication and Media Education]. (2020). URL: http://mediaosvita.org.ua/pro-nas/ [in Ukrainian].

Onkovych, H. (2013). Mediadydaktyka vyshhoji shkoly: ukrajinsjkyj dosvid. [Media didactics of higher school: Ukrainian experience]. Higher Education of Ukraine, 1, 23-29 [in Ukrainian].

Onkovych, H. (2016). Mediapedaghoghika. Mediaosvita. Mediadydaktyka. [Media pedagogics. Media education. Media didactics]. Higher Education of Ukraine, 2, 63-69 [in Ukrainian].

Portal «Mediaosvita i mediaghramotnistj». [Portal Media Education and Media Literacy]. (2020). http://medialiteracy.org.ua/ [in Ukrainian].

Proekty. [Projects]. (2020). Institute of Ecology of Mass Information. http://institutes.Inu.edu.ua/mediaeco/research/projects/ [in Ukrainian].

Recommendations Addressed to the United Nations Educational Scientific and Cultural Organization UNESCO. (1999). Education for the Media and the Digital Age. Vienna: UNESCO [in English].

Slaboshevska, T. M., Smekalkin, I. M. (2013). Mediaosvita v Ukrajini: suchasnyj stan i perspektyvy rozvytku. [Media education in Ukraine: current state and development perspectives]. http://enpuir.npu.edu.ua/bitstream/123456789/

4709/1/Slaboshevska_Smekalin.pdf [in English]. 